Article

\title{
Amino-Modified Silica as Effective Support of the Palladium Catalyst for 4-Nitroaniline Hydrogenation
}

\author{
Adele R. Latypova ${ }^{1, * \mathbb{C}}$, Maxim D. Lebedev ${ }^{1}$, Evgeniy V. Rumyantsev ${ }^{1,2}$, Dmitry V. Filippov ${ }^{1}$, \\ Olga V. Lefedova ${ }^{1}$, Alexey V. Bykov ${ }^{3}$ and Valentin Yu. Doluda ${ }^{1,3}$ \\ 1 Ivanovo State University of Chemistry and Technology, Sheremetevsky ave.7, 153000 Ivanovo, Russia; \\ maxkys2@yandex.ru (M.D.L.); naturer@yandex.ru (E.V.R.); fillipov@isuct.ru (D.V.F.); \\ physchem.606@yandex.ru (O.V.L.); doludav@yandex.ru (V.Y.D.) \\ 2 Federal State Budget Educational Institution of Higher Education «Ivanovo State Polytechnic University», \\ Sheremetevsky ave. 21, 153000 Ivanovo, Russia \\ 3 Tver State Technical University, Nab. A. Nikitina 22, 170042 Tver, Russia; bykovav@yandex.ru \\ * Correspondence: LatAdel@yandex.ru
}

Received: 4 March 2020; Accepted: 29 March 2020; Published: 31 March 2020

check for updates

\begin{abstract}
The article describes the synthesis of aminoorgano-functionalized silica as a prospective material for catalysis application. The amino groups have electron donor properties which are valuable for the metal chemical state of palladium. Therefore, the presence of electron donor groups is important for increasing catalysts' stability. The research is devoted to the investigation of silica amino-modified support influence on the activity and stability of palladium species in 4-nitroaniline hydrogenation process. A series of catalysts with different supports such as $\mathrm{SiO}_{2}, \mathrm{SiO}_{2}-\mathrm{C}_{3} \mathrm{H}_{6}-\mathrm{NH}_{2}$ (amino-functionalized silica), $\gamma-\mathrm{Al}_{2} \mathrm{O}_{3}$ and activated carbon were studied. The catalytic activity was studied in the hydrogenation of 4-nitroaniline to 1,4-phenylenediamine. The catalysts were characterized by scanning electron microscopy, transmission electron microscopy, X-ray photoelectron spectroscopy, Fourier transform infrared spectroscopy and chemisorption of hydrogen by the pulse technique. The $5 \mathrm{wt}$. $\% \mathrm{Pd} / \mathrm{SiO}_{2}-\mathrm{C}_{3} \mathrm{H}_{6}-\mathrm{NH}_{2}$ catalyst exhibited the highest catalytic activity for 4-nitroaniline hydrogenation with $100 \%$ conversion and $99 \%$ selectivity with respect to 1,4-phenylenediamine.
\end{abstract}

Keywords: sol-gel; amino-functionalized silica; catalyst; activity; hydrogenation

\section{Introduction}

Supported catalysts have wide applications in fine organic synthesis [1-4], industrial synthetic processes of petrochemicals [5-7] and pharmaceutical production [8-10]. However, in modern catalysis there is still the problem of increasing the activity and selectivity of catalysts, as well as the search for new catalytically active materials [11-16].

Possible ways to increase catalytic activity and selectivity include the development of catalysts synthesis methods, the optimization of reaction conditions, catalyst modification by different chemical elements and compounds, the application of supports and modification of the catalyst surface [4,11-14,16-20]. Modification of catalyst support surface is one possible solution to increase catalysts' activity and stability. The presence of functional groups on the support surface has great influence on the electronic state of active metal and metal dispersion [21]. The aminopropyl groups provide a unique possibility for further surface modification. Amino groups' modified supports are very useful for further surface nucleophilic substitution and obtaining the highest metal dispersion and study of this effect is a sufficiently novel trend in catalysis [4,19,20,22-25]. A lot of articles are dedicated to the application of amino-functionalized mesoporous silica in medicine, pharmaceutics and smart materials, however, publications on their influence on active metals' catalytic properties 
are fragmental [26-31]. The present study reports the synthesis of aminoorgano-functionalized silica immobilized by palladium nanoparticles using the sol-gel method. This allows the synthesization of various hybrid composition materials by the one-pot method. For comparison, amorphous silica, activated carbon and gamma-alumina were used as supports for palladium particles.

The catalytic activity of synthesized catalysts was tested in 4-nitroaniline hydrogenation (Figure 1). Liquid phase hydrogenation of substituted nitrobenzenes is an essential technology for the production of various aromatic amines-key intermediates for manufacturing agrochemicals, isocyanates, pharmaceuticals and dyes [32-35]. The most commonly used catalysts for different hydrogenation processes contain platinum group metals (palladium, platinum, iridium, etc.) attached to different supports [33-38]. Palladium nanoparticles were found to be the most active and have a high potential for the catalytic application of essential chemical products [33-35]. However, the catalysts' stability is an open issue for such types of catalyst, therefore the development of active and stable catalysts is the focus of the current article.

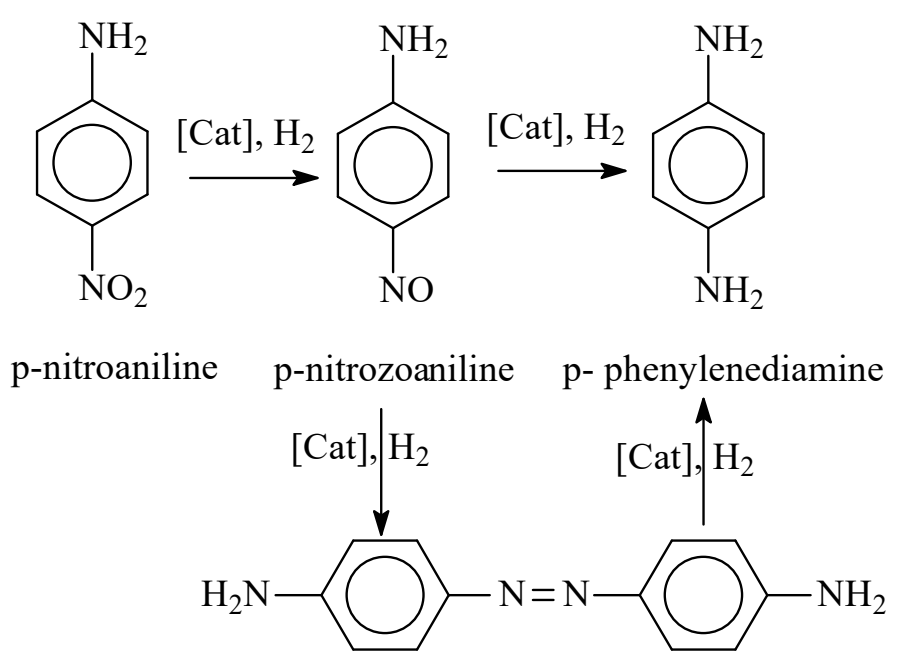

diazodiaminebenzene

Figure 1. The scheme of 4-nitroaniline hydrogenation to 1,4 phenylenediamine.

Compounds such as 4-nitroaniline are used as an industrial raw material to produce agricultural chemicals, rubber compounding agents, synthetic resin additives, polyamides, pharmaceuticals and dyes. The conductive polyamines can be used in electronics [39], and also as antioxidants and preservatives [40-42]. The polyamines can find a wide application in films, materials and membranes due to their biodegradable and electro-conductive properties.

\section{Results and Discussion}

\subsection{FTIR Spectroscopy of Silica Supports}

Silica modification with aminopropyl groups with an $\mathrm{NH}_{2}$ content of $30 \mathrm{wt} . \%$ was verified by Fourier transform infrared spectroscopy (Figure 2). The analysis of the FTIR spectra of modified and pure supports revealed the broad bands centered around $3441 \mathrm{~cm}^{-1}$ and correspond to O-H groups' vibrations. On the other hand, the spectrum of amino-functionalized silic peaks at 2940 and $2886 \mathrm{~cm}^{-1}$ and is assigned to the $\mathrm{C}-\mathrm{H}$ stretching vibrations of $\mathrm{CH}$ - and $-\mathrm{CH}_{2}$ - groups, which can be attributed to the incorporation of the amino group [22,43]. The peak of the $\mathrm{C}-\mathrm{N}$ stretching vibration at $1140 \mathrm{~cm}^{-1}$ overlaps with the Si-O-Si stretching band in the range $1000-1200 \mathrm{~cm}^{-1}$. The peak of the $\mathrm{N}-\mathrm{H}$ stretching vibration at $\sim 3295$ and $3358 \mathrm{~cm}^{-1}$ overlaps with a wide peak of stretching vibration at $\mathrm{O}-\mathrm{H}$ at $3080 \mathrm{~cm}^{-1}$ [22,43]. The intense bands appearing at 1059 and $1176 \mathrm{~cm}^{-1}$ were assigned to the asymmetric stretching vibrations Si-O-Si. The symmetric stretching vibrations of $\mathrm{Si}-\mathrm{O}-\mathrm{Si}$, deformation vibrations of O-Si-O 
and C-Si-O, and in-plane stretching vibrations Si-O can overlap in the 582, 814 and $953 \mathrm{~cm}^{-1}$ range. The bands of Si-O stretching vibrations give reason to suggest the existence of $\mathrm{SiO}_{2}$ network defects. The band observed at $467 \mathrm{~cm}^{-1}$ is assigned to the plane-stretching vibrations of Si-C [43].

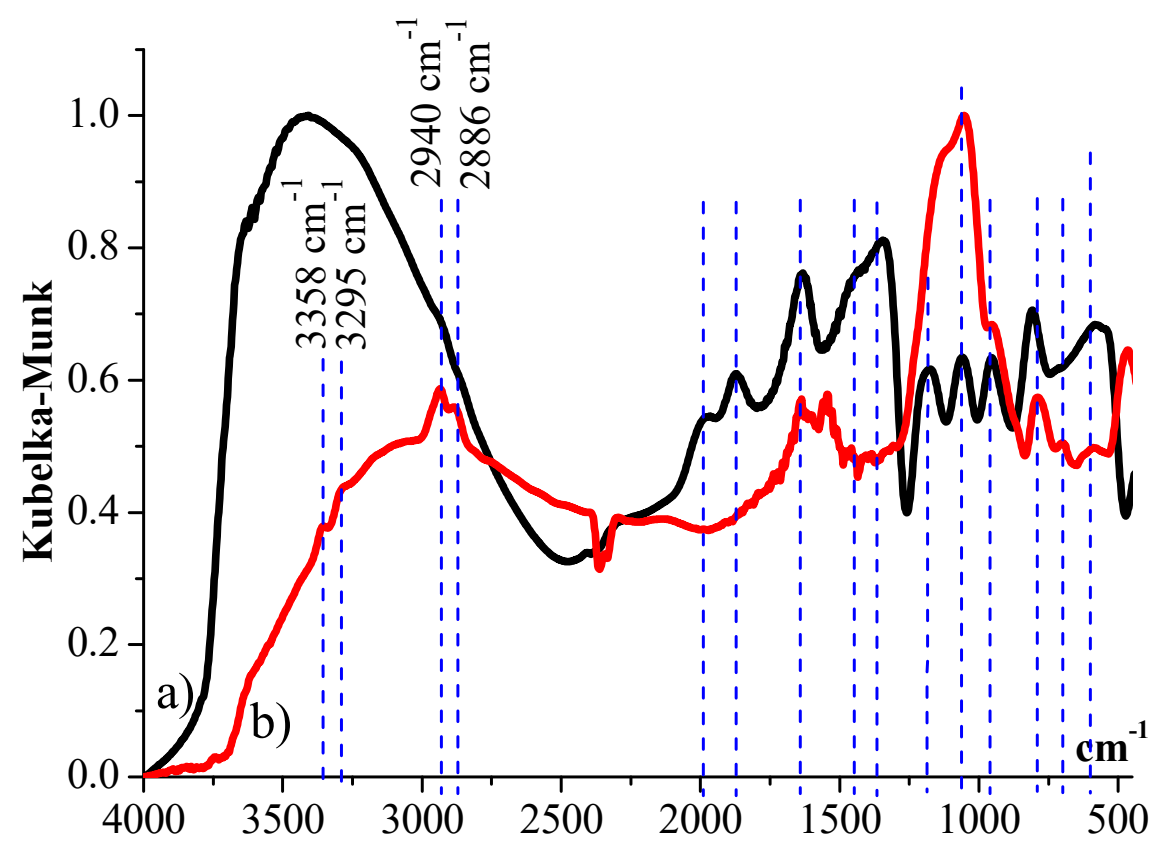

Figure 2. FTIR spectra of supports' surface: (a) $\mathrm{SiO}_{2} ;$ (b) $\mathrm{SiO}_{2}-\mathrm{C}_{3} \mathrm{H}_{6}-(30 \%) \mathrm{NH}_{2}$.

However, the use of tetraethoxysilane as a silica precursor led to the formation of surface methyl-functionalized silica. This was certified by a broad peak in the range $1338-1500 \mathrm{~cm}^{-1}$ which can be assigned to the $\mathrm{C}-\mathrm{H}$ deformation vibrations of aliphatic bands [43].

\subsection{The Pulse Chemisorption}

The hydrogen pulse chemisorption data are presented in Table 1 . Silica surface modification by tetraethoxysilane results in some increase in metal dispersion, and a concentration of active sites and a metallic surface area. However, metal dispersion remains considerably low.

Table 1. Hydrogen pulse chemisorption data.

\begin{tabular}{cccc}
\hline Simple & Metal Dispersion, $\%$ & $\begin{array}{c}\text { Metallic Surface Area, } \\
\mathbf{m}^{2} / \mathbf{g} \text { Metal }\end{array}$ & $\begin{array}{c}\text { Concentration of Active } \\
\text { Center mmol/g }\end{array}$ \\
\hline 5 wt. $\% \mathrm{Pd} / \mathrm{SiO}_{2}-\mathrm{C}_{3} \mathrm{H}_{6}-(30 \%) \mathrm{NH}_{2}$ & 5.0 & 21 & 0.017 \\
\hline $5 \mathrm{wt} . \% \mathrm{Pd} / \mathrm{SiO}_{2}$ & 4.3 & 19 & 0.016 \\
\hline
\end{tabular}

\subsection{XPS of Catalysts before the Reaction}

The surface chemical composition of silica supports determined by X-ray photoelectron spectroscopy. The high-resolution XPS spectra of C 1s, N 1s, Si 2p are shown in the appropriate figure (Figure 3). According to XPS data, the silica contains $\mathrm{O}, \mathrm{C}, \mathrm{Si}$ elements. The synthesized amino-organomodified silica contains $\mathrm{O}, \mathrm{C}, \mathrm{Si}$ and $\mathrm{N}$ elements. 

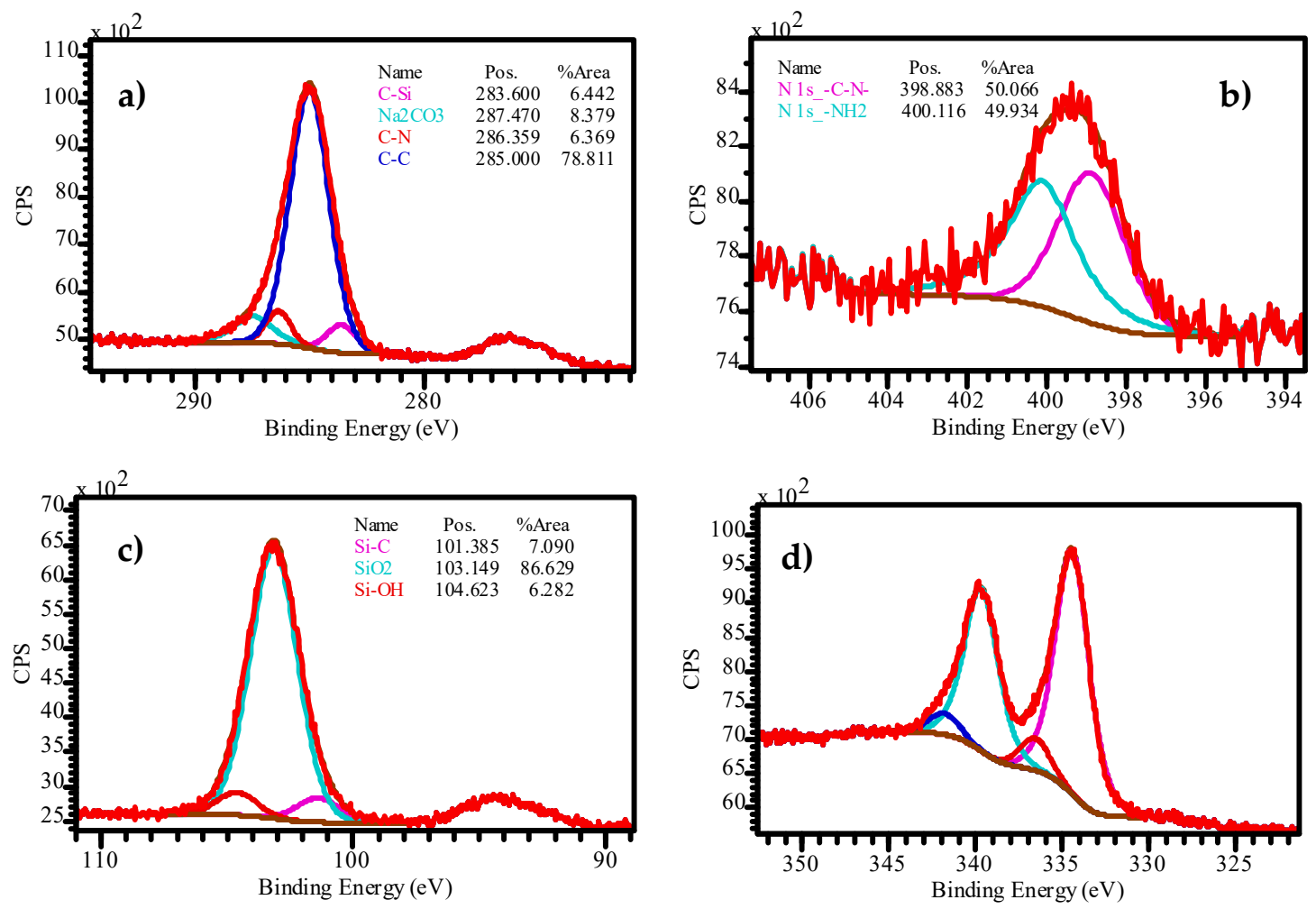

Figure 3. The high-resolution XPS spectra of (a) C 1s; (b) $\mathrm{N} \mathrm{1s;} \mathrm{(c)} \mathrm{Si} \mathrm{2p;} \mathrm{energy} \mathrm{core-level} \mathrm{of}$ $\mathrm{SiO}_{2}-\mathrm{C}_{3} \mathrm{H}_{6}-(30 \%) \mathrm{NH}_{2}$ and (d) $\mathrm{Pd} 3 \mathrm{~d}$ energy core-level of $5 \%$ wt. $\mathrm{Pd} / \mathrm{SiO}_{2}-\mathrm{C}_{3} \mathrm{H}_{6}-(30 \%) \mathrm{NH}_{2}$.

The presence of quantities of aliphatic carbon compounds in silica is a result of the inclusion of an aminopropyl substituent in the silica structure, and the incomplete hydrolysis of silane and carbon pollution. The C-N and C-Si bonds prove the inclusion of aminopropyl substituents in the silicon oxide matrix. According to the published data [43,44], the peaks at 399.5 and $401.6 \mathrm{eV}$ in the spectrum of N 1s can be attributed to C-N and N-H bonds that correlate with the IR-spectroscopy data (Figure 2) $[43,44]$. The bonds -C-ONa belong to molecules of sodium carbonate (Figure 3) [43,44].

Figure $3 \mathrm{~d}$ shows the model decomposition of the XPS high-resolution spectra of Pd $3 \mathrm{~d}$ energy core-level of $5 \%$ wt. $\mathrm{Pd} / \mathrm{SiO}_{2}-\mathrm{C}_{3} \mathrm{H}_{6}-(30 \%) \mathrm{NH}_{2}$ catalyst before the reaction. The XPS data of the other catalysts were published in reference 52 of this paper. The atomic concentration of palladium compounds is given in Table 2. The model decomposition of $\mathrm{Pd} 3 \mathrm{~d}$ spectra for $5 \mathrm{wt} . \% \mathrm{Pd} / \gamma-\mathrm{Al}_{2} \mathrm{O}_{3}$, 5 wt. $\% \mathrm{Pd} / \mathrm{SiO}_{2}$, and $5 \mathrm{wt} . \% \mathrm{Pd} / \mathrm{SiO}_{2}-\mathrm{C}_{3} \mathrm{H}_{6}-(30 \%) \mathrm{NH}_{2}$ catalysts showed the presence of two palladium chemical states (Table 2, Figure 3d) [45]. Different states of palladium were observed in the catalyst of activated carbon, particularly metallic palladium $\mathrm{Pd}^{0}$, oxidized $\mathrm{PdO}$ on metallic $\mathrm{Pd}^{0}$ and palladium oxides $\mathrm{PdO}, \mathrm{PdO}_{2}$ [45].

Table 2. The spectrum data of catalysts before the reaction.

\begin{tabular}{cccc}
\hline Catalyst & Binding Energy, eV & Chemical State & at, $\%$ \\
\hline \multirow{2}{*}{5 wt.\% Pd/SiO} \\
\end{tabular}

An interesting observation was a shift in the binding energy by $\sim 0.5 \mathrm{eV}$ of palladium metal in the $5 \mathrm{wt}$. $\% \mathrm{Pd} \mathrm{SiO}_{2}-\mathrm{C}_{3} \mathrm{H}_{6}-(30 \%) \mathrm{NH}_{2}$ catalyst in comparison to the standard binding energy of 
metal palladium $(335 \mathrm{eV})$. There was an assumption that this may be the result of the displacement of the electron cloud of amino groups to palladium atoms. This effect can take place in case of $\mathrm{Pd}$ nanoparticles' coordination by amino groups. A comparatively similar interaction between palladium nanoparticles and nitrogen-containing supports was reported in several articles devoted to palladium nanostructured materials synthesis and characterization [24,46,47]. Typically, a Pd charging by amino groups has a positive influence on hydrogen chemisorption on active metal that can have a positive effect on the hydrogenation of the substrate $[24,46,47]$.

\subsection{XPS of Used Catalysts}

The atomic surface concentrations of palladium and palladium oxide decrease in $5 \mathrm{wt} . \%$ $\mathrm{Pd} / \gamma-\mathrm{Al}_{2} \mathrm{O}_{3}, 5 \mathrm{wt} . \% \mathrm{Pd} / \mathrm{SiO}_{2}$ and $5 \mathrm{wt} . \% \mathrm{Pd} / \mathrm{C}$ catalysts (Tables 2 and 3) which can be attributed to metal particles' diffusion into a matrix of support [45]. However, for amino-modified sample $5 \mathrm{wt} . \%$ $\mathrm{Pd} / \mathrm{SiO}_{2}-\mathrm{C}_{3} \mathrm{H}_{6}-(30 \%) \mathrm{NH}_{2}$, a change in active metal surface concentration was not observed. The quantity of zero valence metal in $5 \mathrm{wt}$. $\% \mathrm{Pd} / \mathrm{SiO}_{2}$ and $5 \mathrm{wt}$. $\% \mathrm{Pd} / \mathrm{SiO}_{2}-\mathrm{C}_{3} \mathrm{H}_{6}-(30 \%) \mathrm{NH}_{2}$ samples before and after reaction did not change significantly (Table 3 ). The changes in $\mathrm{Pd}^{0}$ surface concentrations in $5 \mathrm{wt} . \%$ $\mathrm{Pd} / \mathrm{C}$ and $\mathrm{Pd} / \gamma-\mathrm{Al}_{2} \mathrm{O}_{3}$ catalysts were the most noticeable [45].

Table 3. The spectrum data of catalysts after used in reaction.

\begin{tabular}{cccc}
\hline Catalyst & Binding Energy, eV & Chemical State & At, \% \\
\hline \multirow{2}{*}{5 wt.\% Pd/SiO} \\
\end{tabular}

In the case of the $5 \mathrm{wt} . \% \mathrm{Pd} / \mathrm{C}$ catalyst, the quantity of $\mathrm{PdO}$ decreased on 0.7 at. $\%$ and the content of $\mathrm{PdO}_{2}$ was increased on 0.7 at.\% (Tables 2 and 3). The contents of $\mathrm{PdO}$ and $\mathrm{Pd}^{0}$ in 5 wt.\% $\mathrm{Pd} / \mathrm{SiO}_{2}$ and $5 \mathrm{wt} . \% \mathrm{Pd} / \gamma-\mathrm{Al}_{2} \mathrm{O}_{3}$ catalysts were decreased.

\subsection{SEM}

The morphology of the amino-functionalized mesoporous silica was studied by scanning electron microscopy (Figure 4). The synthesized silica particles have a spherical shape. Average particle size diameter was found to be $1 \mu \mathrm{m}$ before and after catalysts' synthesis.
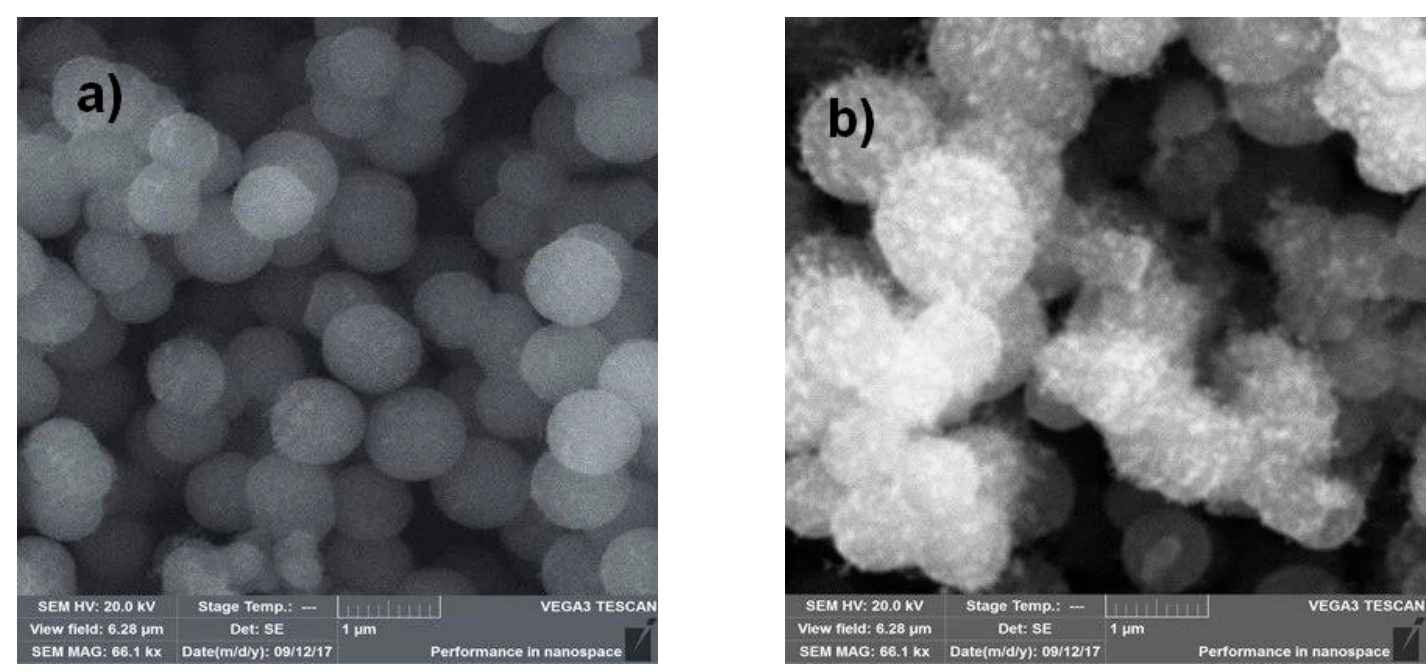

Figure 4. SEM images of (a) $\mathrm{SiO}_{2}-\mathrm{C}_{3} \mathrm{H}_{6}-(30 \%) \mathrm{NH}_{2}$ and (b) 5 wt. $\% \mathrm{Pd} / \mathrm{SiO}_{2}-\mathrm{C}_{3} \mathrm{H}_{6}-(30 \%) \mathrm{NH}_{2}$. 


\subsection{TEM}

The images of transmission electron microscope were obtained for the reliable determination of palladium particle size (Figure 5). The images show that the particles are quite different in size.

a)

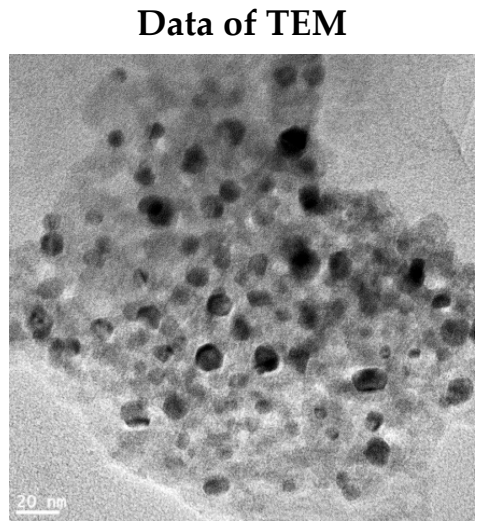

b)

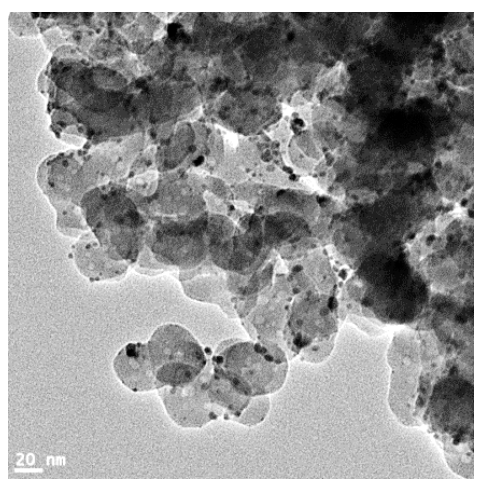

c)

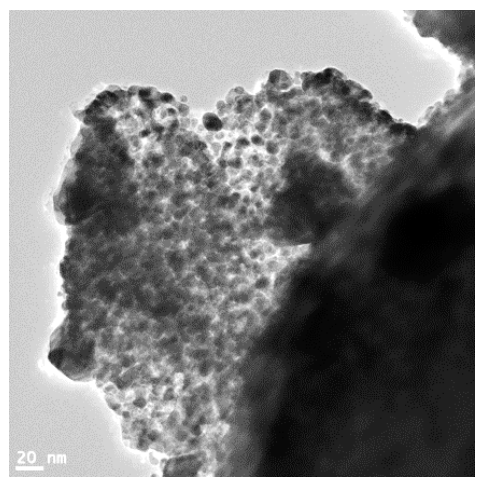

d)

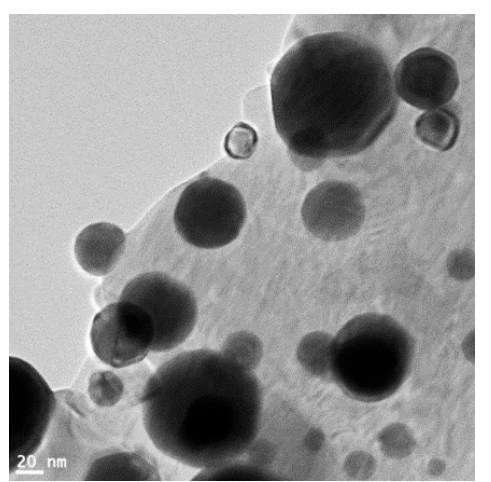

\section{Particle Size Distribution}
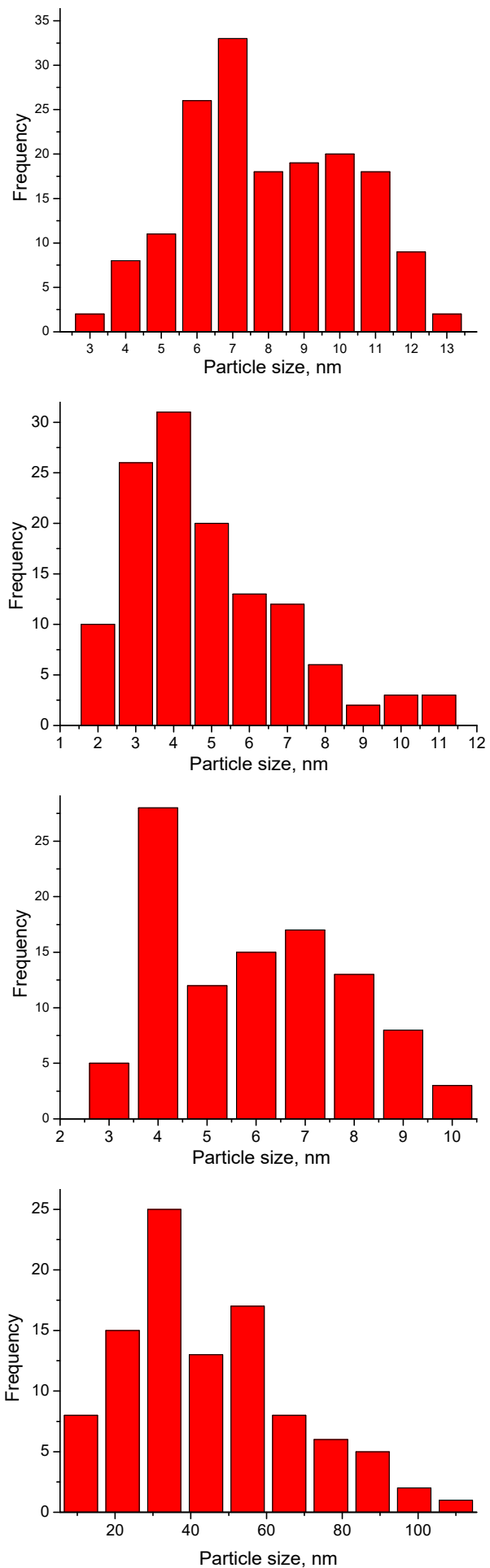

Figure 5. TEM images of catalysts and particle size distribution: (a) 5 wt. $\%$ Pd$/ \gamma-\mathrm{Al}_{2} \mathrm{O}_{3} ;$ (b) 5 wt.\% $\mathrm{Pd} / \mathrm{SiO}_{2}$; (c) 5 wt.\% $\mathrm{Pd} / \mathrm{SiO}_{2}-\mathrm{C}_{3} \mathrm{H}_{6}-\mathrm{NH}_{2} ;$ (d) 5 wt.\% Pd/C. 
The particle size in the $5 \mathrm{wt} . \% \mathrm{Pd} / \mathrm{SiO}_{2}-\mathrm{C}_{3} \mathrm{H}_{6}-(30 \%) \mathrm{NH}_{2}$ catalyst varies from 3 to $10 \mathrm{~nm}$; in the $5 \mathrm{wt} . \% \mathrm{Pd} / \mathrm{SiO}_{2}$ catalyst, particle size varies from 2 to $10 \mathrm{~nm}$; in the $5 \mathrm{wt} . \% \mathrm{Pd} / \gamma-\mathrm{Al}_{2} \mathrm{O}_{3}$ catalyst, particle size varies from 5 to $70 \mathrm{~nm}$; and in the $5 \mathrm{wt} . \% \mathrm{Pd} / \mathrm{C}$ catalyst, particle size varies from 30 to $100 \mathrm{~nm}$. In general, the data agree with the result of hydrogen pulse chemisorption.

Depending on the size of the metal particles, according to both methods (microscopy and pulse chemisorption), the catalysts can be structured in the following row: $5 \mathrm{wt} . \% \mathrm{Pd} / \gamma-\mathrm{Al}_{2} \mathrm{O}_{3} \approx 5 \mathrm{wt} . \% \mathrm{Pd} / \mathrm{C}$ $>5$ wt. $\% \mathrm{Pd} / \mathrm{SiO}_{2}>5$ wt. $\% \mathrm{Pd} / \mathrm{SiO}_{2}-\mathrm{C}_{3} \mathrm{H}_{6}-(30 \%) \mathrm{NH}_{2}$.

The TEM images with a high resolution were used to analyze the atomic lattice parameters of the catalytic phase. The interplanar distance of palladium particles in $5 \mathrm{wt} . \% \mathrm{Pd} / \gamma-\mathrm{Al}_{2} \mathrm{O}_{3}$ is of the order of $\sim 0.14 \mathrm{~nm}$ (220), which corresponds to the metallic palladium phase. Other palladium particles in $5 \mathrm{wt} . \% \mathrm{Pd} / \gamma-\mathrm{Al}_{2} \mathrm{O}_{3}$ with an interplanar distance of about $\sim 0.26 \mathrm{~nm}$ (111) belong to palladium oxide. The interplanar distances of $\sim 0.14 \mathrm{~nm}$ (220) were observed for a catalyst of $5 \mathrm{wt} . \%$ $\mathrm{Pd} / \mathrm{SiO}_{2}-\mathrm{C}_{3} \mathrm{H}_{6}-(30 \%) \mathrm{NH}_{2}$ [48-50]. The TEM data of $5 \mathrm{wt} . \% \mathrm{Pd} / \mathrm{SiO}_{2}$ catalyst also show the interplanar spacings of $\sim 0.14$ (220) and $\sim 0.26 \mathrm{~nm}$ (111) [48-50], which correspond to the metal and oxide state of palladium. The interplanar distances of $\sim 0.14$ (220) and $\sim 0.26 \mathrm{~nm}$ (111) were observed for a catalyst of 5 wt. \% Pd/C [48-50].

\subsection{TPD of Matrices}

According to the results of the TPD $\mathrm{NH}_{3}$ study, the modification of silica by amino groups increased the amount of acid sites compared with silica (Figure 6).

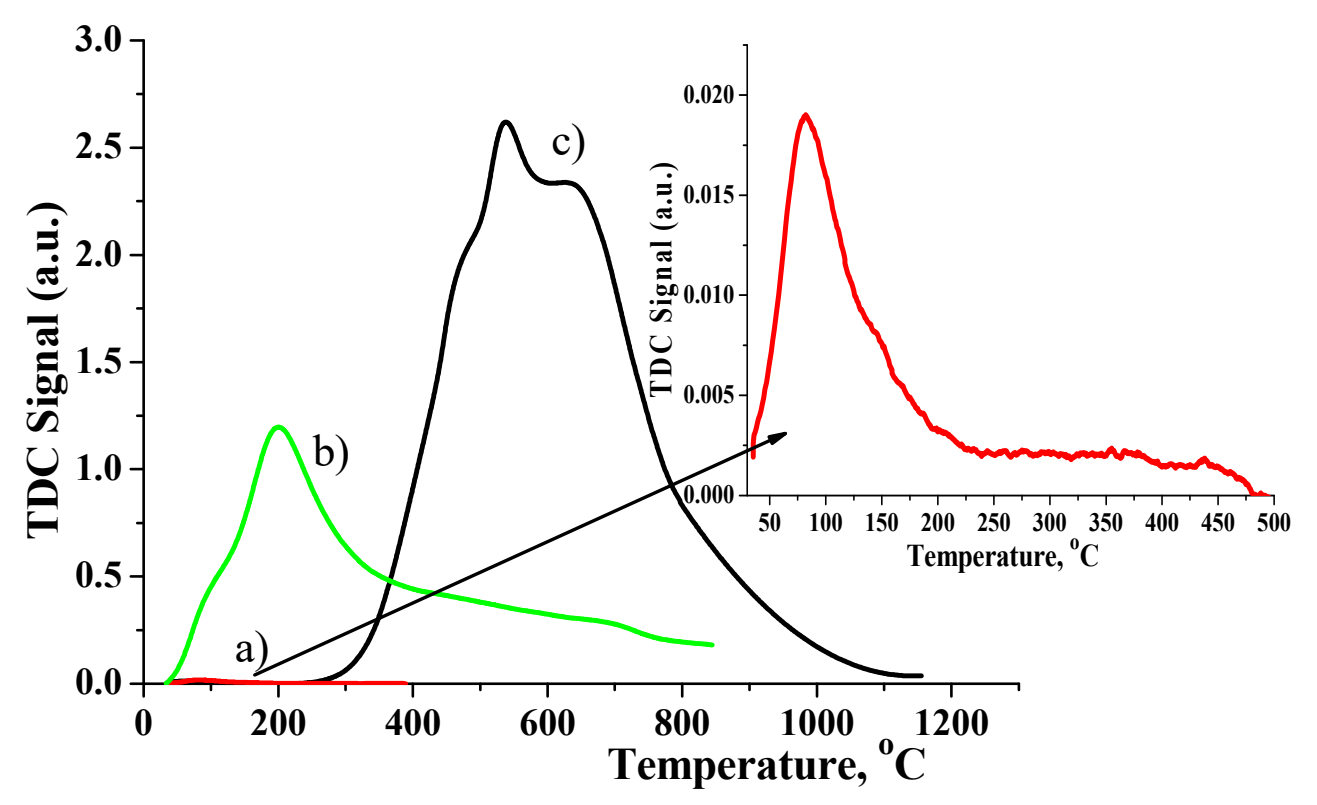

Figure 6. The acid properties of supports. The heating rate was $10{ }^{\circ} \mathrm{C}$ per minute. The composition of gas mixture is $3 \% \mathrm{NH}_{3}$ in He flow. (a) $\mathrm{SiO}_{2}$, (b) $\gamma-\mathrm{Al}_{2} \mathrm{O}_{3}$, (c) $\mathrm{SiO}_{2}-\mathrm{C}_{3} \mathrm{H}_{6}-\mathrm{NH}_{2}$.

The alumina contains less acidic properties than amino-modified silica. Thus, according to the quantity and acid sites' strength, the catalyst supports can be given in the following order: $\mathrm{SiO}_{2}-\mathrm{C}_{3} \mathrm{H}_{6}-\mathrm{NH}_{2}>\gamma-\mathrm{Al}_{2} \mathrm{O}_{3}>\mathrm{SiO}_{2}$.

\subsection{The Activity of Synthesized Catalysts}

In all cycles for all catalysts, the conversion of 4-nitroaniline to 1,4-phenylenediamine was $100 \%$. A sufficient quantity of hydrogen for completely reduce to 4-nitroaniline is $3.62 \mathrm{mmol}$. Thus, according to the data of the catalysts, activity can arrange in the order: $5 \mathrm{wt} . \% \mathrm{Pd} / \mathrm{SiO}_{2}-\mathrm{C}_{3} \mathrm{H}_{6}-(30 \%) \mathrm{NH}_{2}$ 
$\left(10.1 \mathrm{~mole} / \mathrm{sec} \cdot 10^{-5}\right)>$ Raney nickel $\left(4.8 \mathrm{~mole} / \mathrm{sec} \cdot \cdot 10^{-5}\right)[51]>5 \mathrm{wt} . \% \mathrm{Pd} / \mathrm{C}\left(4.4 \mathrm{~mole} / \mathrm{sec} \cdot 10^{-5}\right) \approx 5 \mathrm{wt} . \%$ $\mathrm{Pd} / \gamma-\mathrm{Al}_{2} \mathrm{O}_{3}\left(4.4\right.$ mole/sec. $\left.10^{-5}\right)>5 \mathrm{wt} . \% \mathrm{Pd} / \mathrm{SiO}_{2}\left(0.8 \mathrm{~mole} / \mathrm{sec} .10^{-5}\right)$ (Figure 7 , Table 4$)$.

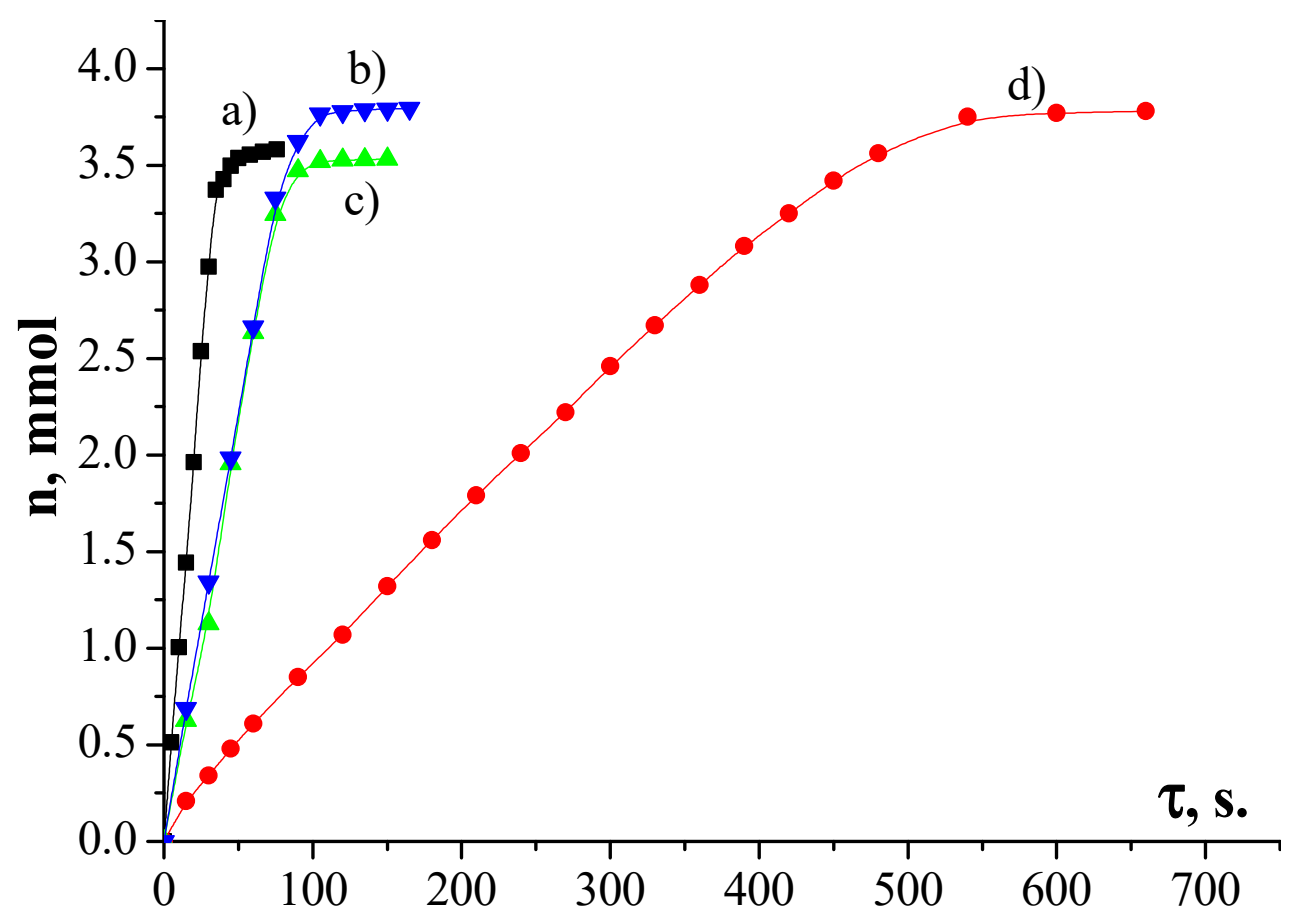

Figure 7. Kinetic curves of hydrogen uptake in the 4-nitroaniline hydrogenation in aqueous 2-propanol (0.68 mol fraction). $\mathrm{T}=298 \mathrm{~K}, \mathrm{~m}_{\text {(cat) }}=0.30 \pm 0.05 \mathrm{~g} ., \mathrm{m}_{\text {(NA) }}=0.50 \pm 0.05$ g. (a) 5 wt. $\%$ $\mathrm{Pd} / \mathrm{SiO}_{2}-\mathrm{C}_{3} \mathrm{H}_{6}-(30 \%) \mathrm{NH}_{2}$; (b) 5 wt.\% Pd/C; (c) 5 wt.\% $\mathrm{Pd} / \gamma-\mathrm{Al}_{2} \mathrm{O}_{3}$; (d) 5 wt. \% $\mathrm{Pd} / \mathrm{SiO}_{2}$.

Table 4. Catalytic recyclability test for a successive five cycles of 4-nitroaniline hydrogenation.

\begin{tabular}{|c|c|c|c|c|c|}
\hline \multirow{2}{*}{ Catalyst } & \multicolumn{5}{|c|}{ The Hydrogen Consumption Rate $10^{-5} \operatorname{Mole}\left(\mathrm{H}_{2}\right) / \mathrm{sec}$. } \\
\hline & 1 run & 2 run & 3 run & 4 run & 5 run \\
\hline 5 wt. $\% \mathrm{Pd} / \mathrm{SiO}_{2}-\mathrm{C}_{3} \mathrm{H}_{6}-(30 \%) \mathrm{NH}_{2}$ & 10.1 & 9.5 & 8.8 & 8.3 & 8.0 \\
\hline 5 wt. $\% \mathrm{Pd} / \mathrm{SiO}_{2}[45,52]$ & 0.8 & 0.8 & 0.8 & 0.7 & 0.6 \\
\hline
\end{tabular}

A drastic increase in the catalytic activity for $\mathrm{Pd} / \mathrm{SiO}_{2}-\mathrm{C}_{3} \mathrm{H}_{6}-(30 \%) \mathrm{NH}_{2}$ sample compared to $\mathrm{Pd} / \mathrm{SiO}_{2}$ can be subscribed to an increase in the active surface as a result of some decrease in $\mathrm{Pd}$ nanoparticles' average diameter. However, Pd nanoparticles' surface modification by aminogroups and a sift in electron density to $\mathrm{Pd}$ nanoparticles can be the main reason for the increase in $\mathrm{Pd}$ activity $[24,46,47]$.

Comparison of the catalysts' activity after a catalyst recycle showed that the highest activity after five reaction cycles was observed for $5 \mathrm{wt} . \% \mathrm{Pd} / \mathrm{SiO}_{2}-\mathrm{C}_{3} \mathrm{H}_{6}-(30 \%) \mathrm{NH}_{2}$ (Table 4, Figure 7). The catalysts' stability can be arranged in the following order: 5 wt. $\% \mathrm{Pd} / \mathrm{SiO}_{2}-\mathrm{C}_{3} \mathrm{H}_{6}-(30 \%) \mathrm{NH}_{2}>5 \mathrm{wt} . \% \mathrm{Pd} / \mathrm{SiO}_{2}>$ $5 \mathrm{wt} . \% \mathrm{Pd} / \mathrm{C} \approx 5 \mathrm{wt} . \% \mathrm{Pd} / \gamma-\mathrm{Al}_{2} \mathrm{O}_{3}$.

Gas chromatographic analysis made it possible to calculate the yield of 1,4-phenylenediamine in the hydrogenation reaction after each repeated addition of 4-nitroaniline (Table 5). In all samples, at the end of the reaction, in each input of 4-nitroaniline, traces of the initial compound were not detected, and the hydrogenation conversion of 4-nitroaniline was considered to be close to full conversion.

Analysis of 4-nitroaniline conversion rate and the formation of 1,4-phenylenediamine showed a similar tendency to decrease in the values of the rates, as for the consumption of hydrogen (Table 4). 
Table 5. Data of gas chromatographic analysis in hydrogenation of 4-nitroaniline to 1,4-phenylenediamine.

\begin{tabular}{ccc}
\hline Catalyst & $\begin{array}{c}\text { Conversion * of } \\
\text { 4-nitroaniline }\end{array}$ & $\begin{array}{c}\text { Yields * of } \\
\text { 1,4-phenylenediamine }\end{array}$ \\
\hline 5 wt. $\% \mathrm{Pd} / \mathrm{SiO}_{2}-\mathrm{C}_{3} \mathrm{H}_{6}-(30 \%) \mathrm{NH}_{2}$ & 100 & 100 \\
5 wt. $\% \mathrm{Pd} / \mathrm{C}$ & 100 & 100 \\
$5 \mathrm{wt} \% \mathrm{Pd} / \mathrm{SiO}_{2}$ & 100 & 100 \\
5 wt. $\% \mathrm{Pd} / \gamma-\mathrm{Al}_{2} \mathrm{O}_{3}$ & 100 & 100 \\
\hline
\end{tabular}

* in each reaction cycle.

The second catalyst with a lower content of amino groups was obtained to confirm the effect of the number of amino groups on the surface.

A kinetic experiment showed that the activity of the $5 \mathrm{wt} . \% \mathrm{Pd} / \mathrm{SiO}_{2}-\mathrm{C}_{3} \mathrm{H}_{6}-(30 \%) \mathrm{NH}_{2}$ catalyst with an $\mathrm{NH}_{2}$ content of $30 \mathrm{wt} . \%$ is two times higher than the $5 \mathrm{wt} . \% \mathrm{Pd} / \mathrm{SiO}_{2}-\mathrm{C}_{3} \mathrm{H}_{6}-(10 \%) \mathrm{NH}_{2}$ catalyst with a content of $10 \mathrm{wt} . \% \mathrm{NH}_{2}$ groups: $10.1 \cdot 10^{-5}$ mole $\left(\mathrm{H}_{2}\right) / \mathrm{sec}$ and $5.5 \cdot 10^{-5}$ mole $\left(\mathrm{H}_{2}\right) / \mathrm{sec}$. Kinetic curves of the hydrogen uptake of the catalytic hydrogenation of 4-nitroaniline on organically modified catalysts are shown in Figure 8. The higher the concentration of amino groups on the matrix surface was fixed, the more active the palladium deposited on the silica matrix [24,46,47].

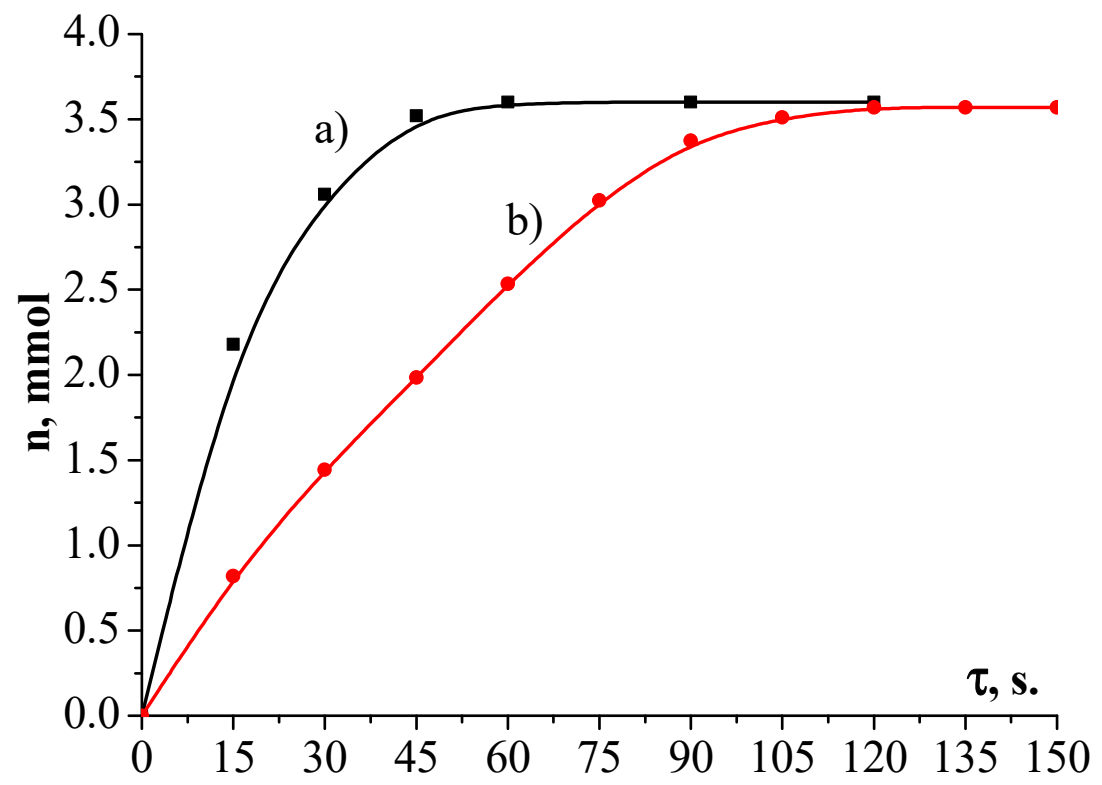

Figure 8. Kinetic curves of hydrogen uptake in the 4-nitroaniline hydrogenation in aqueous 2-propanol (0.68 mol fraction). $\mathrm{T}=298 \mathrm{~K}, \mathrm{~m}_{\text {(cat) }}=0.30 \pm 0.05 \mathrm{~g}$., $\mathrm{m}_{(\mathrm{NA})}=0.50 \pm 0.05 \mathrm{~g}$. (a) $5 \mathrm{wt} \%$ $\mathrm{Pd} / \mathrm{SiO}_{2}-\mathrm{C}_{3} \mathrm{H}_{6}-(30 \%) \mathrm{NH}_{2}$; (b) 5 wt. $\% \mathrm{Pd} / \mathrm{SiO}_{2}-\mathrm{C}_{3} \mathrm{H}_{6}-(10 \%) \mathrm{NH}_{2}$.

According to gas chromatography analysis, the conversion of 4-nitroaniline and the yield of 1.4-phenylenediamine also amounted to $100 \%$.

\section{Materials and Methods}

\subsection{Chemicals and Materials}

Tetraethoxysilane (99.9 wt.\% Vecton, St. Petersburg, Russia), 2-propanol (99 wt.\% Vecton, St. Petersburg, Russia) aminopropyltrimetoxysilane (97 wt.\%, Sigma Aldrich, Hamburg, Germany), dodecyldimetylamine N-oxyde (30 wt.\% solution in water, Sigma Aldrich, Saint-Quentin-Fallavier, France), Cyclohexane (99 wt.\%, ECOS-1, Moscow, Russia), sodium carbonate (Vecton, St. Petersburg, Russia), hydrochloric acid (Vecton, St. Petersburg, Russia), palladium chloride $\left(\mathrm{PdCl}_{2} \cdot 2 \mathrm{H}_{2} \mathrm{O}\right.$, JSC "Aurat", Moscow, Russia), aqueous ammonia solution (60 wt.\%, Vecton, St. Petersburg, Russia) the 
high-purity gases $\left(\mathrm{H}_{2} 99.998 \%\right.$, $\left.\mathrm{Ar} 99,99 \%\right)$ for the catalyst synthesis were used. The $\gamma-\mathrm{Al}_{2} \mathrm{O}_{3}$ and activated carbon ARD-2 were purchased from Reachim Ltd. Russia and were used for catalyst synthesis as received.

\subsection{Sol-Gel Method}

\subsubsection{Synthesis of Silica}

To synthesize spherical silica nanoparticles, $700 \mathrm{~mL}$ of distilled water was added to $500 \mathrm{~mL}$ of 2-propanol in a flat-bottomed flask and the solution was stirred to obtain a uniform solution. Then, $200 \mathrm{~mL}$ of tetraethoxysilane was added to the solution. The reaction mixture was kept under vigorous stirring for $30 \mathrm{~min}$ with a mixing rate of $1500 \mathrm{rpm}$. Subsequently, $50 \mathrm{~mL}$ of aqueous ammonia solution (60 wt.\%) was added dropwise to the reaction mixture over $30 \mathrm{~min}$. The mixture was stirred for $2 \mathrm{~h}$ with a mixing rate of $1000 \mathrm{rpm}$. Then, the precipitate was filtered, washed with distilled water and dried at $200^{\circ} \mathrm{C}$ for $3 \mathrm{~h}$ on air.

\subsubsection{Synthesis of Amino-Functionalized Silica}

The first step of the reaction procedure was to prepare the oil/water emulsion. For this, $104 \mathrm{~mL}$ of distillated water and $16 \mathrm{~mL}$ of pure ethanol were mixed with a stirrer with a mixing rate $1500 \mathrm{rpm}$. Then, $2 \mathrm{~mL}$ of cyclohexane was added as a co-template. After the addition of $4.8 \mathrm{~mL}$ of dodecyldimetylamine $\mathrm{N}$-oxyde to the solution, the formation of emulsion was observed. To achieve a higher emulsion dispersion, the mixture was treated by ultrasound for $5 \mathrm{~min}$ in ultrasonic bath $36-42 \mathrm{kHz}, 200 \mathrm{~W}$. In order to homogenize the reaction mixture, an extra $0.2 \mathrm{~mL}$ of surfactant was added. Then, $0.8 \mathrm{~mL}$ for $\mathrm{SiO}_{2}-\mathrm{C}_{3} \mathrm{H}_{6}-(30 \%) \mathrm{NH}_{2}$ and $0.3 \mathrm{~mL}$ for $\mathrm{SiO}_{2}-\mathrm{C}_{3} \mathrm{H}_{6}-(10 \%) \mathrm{NH}_{2}$ of aminopropyltrimetoxysilane were adjusted in the system for particles' formation. The solution was stirred for $10 \mathrm{~min}$ at a reaction temperature $60{ }^{\circ} \mathrm{C}$. Then first portion of tetraethoxysilane $(1 \mathrm{~mL})$ was added to the mixture and solution opalescence was immediately observed. The solution was stirred for $24 \mathrm{~h}$ at room temperature. The final solution was a viscous colloid of white color, which was sufficiently stable. A vacuum filtration of solution with 0.2 micrometers membrane filter was used to separate the dispersed phase from the solution. The material was dried in vacuum oven at pressure of 0.4 bar and temperature of $100^{\circ} \mathrm{C}$.

\subsection{Catalyst Preparation}

The synthesis of Pd-based catalysts was made by the precipitation of palladium hydroxide due to hydrolysis reaction by the addition of $3 \mathrm{mM} \mathrm{H}_{2} \mathrm{PdCl}_{4}$ solution in water to $1 \mathrm{~g}$ of support $\left(\mathrm{SiO}_{2}\right.$, $\gamma-\mathrm{Al}_{2} \mathrm{O}_{3}$ or activated carbon) suspended in a $40 \mathrm{~mL}$ aqueous solution of $0.1 \mathrm{M} \mathrm{Na}_{2} \mathrm{CO}_{3}$ and $0.1 \mathrm{M}$ solution of sodium dodecyl sulfate using an ultrasonic bath (Bandelin, 10P, Mannheim, Germany). The solution of $\mathrm{H}_{2} \mathrm{PdCl}_{4}$ was prepared in $0.2 \mathrm{M}$ hydrochloric acid. The suspension was mixed for $3 \mathrm{~h}$ at $35^{\circ} \mathrm{C}$ in an ultrasonic bath. The catalysts sample was filtered, thoroughly washed with distilled water and dried at $65^{\circ} \mathrm{C}$ under air. Prior to kinetic experiments, catalysts' sample was reduced at $250{ }^{\circ} \mathrm{C}$ for $60 \mathrm{~min}$ in the hydrogen flow in tube furnace than cooled to ambient temperature and flashed with nitrogen and immediately transferred to the catalytic reactor. The following samples were synthesized by this methodology and denoted as $5 \mathrm{wt} . \% \mathrm{Pd} / \gamma-\mathrm{Al}_{2} \mathrm{O}_{3}, 5 \mathrm{wt} . \% \mathrm{Pd} / \mathrm{SiO}_{2}, 5 \mathrm{wt} . \% \mathrm{Pd} / \mathrm{C}, 5$ wt.\% $\mathrm{Pd} / \mathrm{SiO}_{2}-\mathrm{C}_{3} \mathrm{H}_{6}-\mathrm{NH}_{2}$, with an $\mathrm{NH}_{2}$ content of 30 wt.\%.

\subsection{Catalyst Characterization}

\subsubsection{Fourier Transform Infrared Spectroscopy (FTIR)}

The diffuse reflectance IR spectroscopy was carried out using the FTIR spectrometer IRPrestige-21 (Shimadzu, Kyoto, Japan) equipped with a diffuse reflection attachment. DRS-8000 was used for the 
qualitative composition of catalyst surface. The resolution of all spectra was $4 \mathrm{~cm}^{-1}$ and spectra were registered in the wave number range $490-4000 \mathrm{~cm}^{-1}$.

\subsubsection{Hydrogen Pulse Chemisorption}

The metal dispersion and the chemically active surface area were determined due to pulse chemisorption analysis by applying a pulsed titration of the catalyst with a hydrogen. The spectra were registered on an automatic analyzer of chemosorption AutoChem HP 2950 (Micromeritics, Norcross, GA, USA).

\subsubsection{XPS}

X-ray photoelectron spectroscopy (XPS) data were obtained using ES-2403 spectrometer (manufacturer: Institute for Analytic Instrumentation of RAS, St. Petersburg, Russia) with anode Mg $\mathrm{K} \alpha(\mathrm{h} v=1253.6 \mathrm{eV})$, energy analyzer PHOIBOS 100-MCD5 (SPECS, Berlin, Germany) and X-Ray source XR-50 (SPECS, Berlin, Germany). All the data were acquired at an X-ray power of $250 \mathrm{~W}$. Survey spectra were recorded at an energy step of $0.5 \mathrm{eV}$ with the analyzer pass energy $40 \mathrm{eV}$, and high resolution spectra were recorded at an energy step of $0.05 \mathrm{eV}$ with the analyzer pass energy $7 \mathrm{eV}$. Samples were degassed within $180 \mathrm{~min}$ before analysis and were stable during the treatment. The obtained spectra were analyzed using CasaXPS software taking sensitivity factors in the quantity analysis of data into account.

\subsubsection{SEM}

The morphological characteristics of the amino-functionalized mesoporous silica and catalyst were examined by scanning electron microscopy (SEM, TESCAN, Vega-LSU) equipped with X-ray microanalysis (OXFORD INCA PentaFETx3). Scanning electron microscope images were acquired at a magnification of $66.1 \mathrm{kX}$ at $20 \mathrm{kV}$ with an SE detector.

\subsubsection{TEM}

The structural properties of the samples were examined using an electron microscope (JEM-2200FS, accelerating voltage $200 \mathrm{kV}$ ) in the transmission high-resolution electron microscopy mode (PFEM, high-resolution transmission electron microscopy-HRTEM). A model of the microscope JEOL JEM-2200FS showed an accelerating voltage of $200 \mathrm{kV}$. Resolution: by points $-0.19 \mathrm{~nm}$; on the lattice $-0.1 \mathrm{~nm}$; in the mapping mode $-0.2 \mathrm{~nm}$; in the HAADF mode $-0.14 \mathrm{~nm}$. For the analysis of the elemental composition, electron microscopy was used in the energy dispersive $\mathrm{X}$-ray spectroscopy mode (EMF, energy-dispersive X-ray spectroscopy (EDS)).

\subsubsection{Temperature Programmed Desorption (TPD) of $\mathrm{NH}_{3}$}

The study of support acid properties was provided by AutoChem HP 2950 automatic chemisorption analyzer (Micromeritics, Norcross, GA, USA). The high purity grade helium was used by way of carrier gas. The signal was recorded by a heat conductivity detector. The studied sample was pre-processed in mixture $3 \% \mathrm{NH}_{3}$-He flow at room temperature. The excess of $\mathrm{NH}_{3}$ gas was desorbed by flushing the system with helium upon gradual heating with a rate of $10 \% \mathrm{~min}$. The desorption of $\mathrm{NH}_{3}$ was carried by heating the sample up to $950^{\circ} \mathrm{C}$ with a constant heating rate of $10^{\circ} \mathrm{C}$ per minute. Then, the sample was cooled to ambient temperature.

\subsubsection{Catalysts Activity Experiments Description}

The stirred reactor with the temperature-control was used to carry out 4-nitroaniline hydrogenation to 1,4-phenylenediamine. The catalysts $5 \mathrm{wt} . \% \mathrm{Pd} / \mathrm{SiO}_{2}-\mathrm{C}_{3} \mathrm{H}_{6}-\mathrm{NH}_{2}, 5 \mathrm{wt} . \% \mathrm{Pd} / \mathrm{SiO}_{2}, 5 \mathrm{wt} . \% \mathrm{Pd} / \gamma-\mathrm{Al}_{2} \mathrm{O}_{3}$ and $5 \mathrm{wt} . \% \mathrm{Pd} / \mathrm{C}$ were tested in the hydrogenation of 4-nitroaniline in the environment of a water solution of 2-propanol (0.68 mole fraction). Before experiments, the reactor was flushed three times with 
hydrogen for air removal. The reaction rates were defined by volumetric measurements of hydrogen consumption. The rates of reaction were calculated as an inclination angle tangent of kinetic curves of hydrogen consumption. The test for the contribution of homogeneous catalysis to the reaction rate was performed by Sheldon's filtration test methodology. After the partial conversion of 4-nitroaniline, the reaction stopped and the catalyst was extracted by filtration. Further to this, the reaction was continued without catalyst, but chemical transformation wasn't observed. Thus, the hydrogenation was catalyzed only by heterogeneous catalysts.

Chromatographic analysis was performed using a gas chromatograph (Crystal, manufacturer Chromatek, Yoshkar-Ola, Russia). The reaction rate was controlled through the 4-nitroaniline conversion. After completion, the catalyst was separated from the reaction mixture by centrifugation.

\subsubsection{Deactivation Experiments Using Recovered Catalysts}

The deactivation of catalysts was studied by the hydrogenation of 4-nitroaniline to 1,4-phenylenediamine in a water solution of 2-propanol with the repeated injection of 4-nitroaniline at the end of reaction. Five repeated injections of 4-nitroaniline were carried out on each catalyst.

\section{Conclusions}

Silica surface modification with aminopropyltrimetoxysilane allows the effective synthesis of catalytically active Pd nanoparticles with diameters varying from 3 to $10 \mathrm{~nm}$. Pd species mainly present in the form of metal palladium and palladium oxide(II). Silica surface modification with amino groups results in a higher palladium surface concentration $(2.12 \mathrm{at} \%)$ compared to unmodified silica (1.47 at \%) according to XPS data. This results in an increase in sample activity in p-nitroaniline hydrogenation reaction up to $10.1 \mathrm{~mole}\left(\mathrm{H}_{2}\right) /$ sec. $\cdot 10^{-5}$ for $5 \mathrm{wt} . \% \mathrm{Pd} / \mathrm{SiO}_{2}-\mathrm{C}_{3} \mathrm{H}_{6}-(30 \%) \mathrm{NH}_{2}$ compared to 0.8 mole $\left(\mathrm{H}_{2}\right) / \mathrm{sec} \cdot 10^{-5}$ for the unmodified sample $5 \mathrm{wt} . \% \mathrm{Pd} / \mathrm{SiO}_{2}$.

The comparison of TPD and kinetics data shows a certain correlation. The higher the acidity of the support, the higher the activity of supported palladium.

An increase in surface aminogroups concentration in the case of samples $5 \mathrm{wt} . \% \mathrm{Pd} / \mathrm{SiO}_{2}-$ $\mathrm{C}_{3} \mathrm{H}_{6}-(30 \%) \mathrm{NH}_{2}$ and 5 wt. $\% \mathrm{Pd} / \mathrm{SiO}_{2}-\mathrm{C}_{3} \mathrm{H}_{6}-(10 \%) \mathrm{NH}_{2}$ results in an appropriate increase in catalytic activity by 1.9 times. This confirms the hypothesis that the electron-donating properties of the amino group have a positive effect on the catalytic activity of the supported metal. This also confirms the kinetic experiments using an unmodified, commonly used Pd supported on activated carbon, alumina and Raney nickel samples. Silica surface modification with amino aminopropyltrimetoxysilane has a positive influence on catalyst stability because of palladium nanoparticles' strong interaction with silica compare to unmodified support.

Author Contributions: Conceptualization, E.V.R.; Formal analysis, A.R.L., E.V.R., D.V.F. and A.V.B.; Investigation, A.R.L., M.D.L. and A.V.B.; Methodology, D.V.F.; Project administration, E.V.R. and O.V.L.; Supervision, V.Y.D.; Visualization, A.R.L.; Writing—original draft, A.R.L. and D.V.F.; Writing一review \& editing, V.Y.D. All authors have read and agreed to the published version of the manuscript.

Funding: The work was funded by the Russian Science Foundation Grant No. 18-79-10157.

Conflicts of Interest: The authors declare no conflicts of interest.

\section{References}

1. Gómez, J.E.; Kleij, A.W. Chapter Three-Catalytic nonreductive valorization of carbon dioxide into fine chemicals. In Advances in Organometallic Chemistry; Pérez, P.J., Ed.; Academic Press: Cambridge, MA, USA, 2019; Volume 71, pp. 175-226. [CrossRef]

2. Gabriele, B. Chapter 3-Synthesis of Heterocycles by Palladium-Catalyzed Carbonylative Reactions. In Advances in Transition-Metal Mediated Heterocyclic Synthesis; Solé, D., Fernández, I., Eds.; Academic Press: Cambridge, MA, USA, 2018; pp. 55-127. [CrossRef]

3. Masuda, K.; Ichitsuka, T.; Koumura, N.; Sato, K.; Kobayashi, S. Flow fine synthesis with heterogeneous catalysts. Tetrahedron 2018, 74, 1705-1730. [CrossRef] 
4. Yokoi, T.; Kubota, Y.; Tatsumi, T. Amino-functionalized mesoporous silica as base catalyst and adsorbent. Appl. Catal. A Gen. 2012, 421, 14-37. [CrossRef]

5. Hocking, M.B. 19-PETROCHEMICALS. In Handbook of Chemical Technology and Pollution Control; Hocking, M.B., Ed.; Academic Press: San Diego, CA, USA, 1998; pp. 633-664. [CrossRef]

6. Speight, J.G. Chapter 3-Industrial Organic Chemistry. In Environmental Organic Chemistry for Engineers; Speight, J.G., Ed.; Butterworth-Heinemann: Oxford, UK, 2017; pp. 87-151. [CrossRef]

7. Vedrine, J.C. 8-Main industrial processes using metal oxides as catalysts or support and future trends in heterogeneous catalysis. In Metal Oxides in Heterogeneous Catalysis; Védrine, J.C., Ed.; Elsevier: Amsterdam, The Netherlands, 2018; pp. 401-549. [CrossRef]

8. Kelkar, A.A. Chapter 14-Carbonylations and Hydroformylations for Fine Chemicals. In Industrial Catalytic Processes for Fine and Specialty Chemicals; Joshi, S.S., Ranade, V.V., Eds.; Elsevier: Amsterdam, The Netherlands, 2016; pp. 663-692. [CrossRef]

9. Borah, B.J.; Mondal, M.; Bharali, P. Chapter 27-Palladium-Based Hybrid Nanocatalysts: Application toward Reduction Reactions. In Noble Metal-Metal Oxide Hybrid Nanoparticles; Mohapatra, S., Nguyen, T.A., Nguyen-Tri, P., Eds.; Woodhead Publishing: Cambridge, UK, 2019; pp. 565-583. [CrossRef]

10. Albéniz, A.C.; Casares, J.A. Chapter One-Palladium-Mediated Organofluorine Chemistry. In Advances in Organometallic Chemistry; Pérez, P.J., Ed.; Academic Press: Cambridge, MA, USA, 2014; Volume 62, pp. 1-110. [CrossRef]

11. Zhang, R.; Xue, M.; Wang, B.; Ling, L. Acetylene selective hydrogenation over different size of Pd-modified $\mathrm{Cu}$ cluster catalysts: Effects of Pd ensemble and cluster size on the selectivity and activity. Appl. Surf. Sci. 2019, 481, 421-432. [CrossRef]

12. Yang, Q.; Hou, R.; Sun, K. Tuning butene selectivities by $\mathrm{Cu}$ modification on Pd-based catalyst for the selective hydrogenation of 1, 3-butadiene. J. Catal. 2019, 374, 12-23. [CrossRef]

13. Eslava, J.L.; Gallegos-Suárez, E.; Guerrero-Ruiz, A.; Rodríguez-Ramos, I. Effect of Mo promotion on the activity and selectivity of $\mathrm{Ru} / \mathrm{Graphite}$ catalysts for Fischer-Tropsch synthesis. Catal. Today 2019. [CrossRef]

14. He, Z.-H.; Li, N.; Wang, K.; Wang, W.-T.; Liu, Z.-T. Selective hydrogenation of quinolines over a CoCu bimetallic catalyst at low temperature. Mol. Catal. 2019, 470, 120-126. [CrossRef]

15. Chakoli, A.N.; Sadeghzadeh, M. Chapter 27-Recent Trends in Biomedical and Pharmaceutical Industry Due to Engineered Nanomaterials. In Handbook of Nanomaterials for Industrial Applications; Mustansar Hussain, C., Ed.; Elsevier: Amsterdam, The Netherlands, 2018; pp. 499-519. [CrossRef]

16. Zhu, J.; Wood, J.; Deplanche, K.; Mikheenko, I.; Macaskie, L.E. Selective hydrogenation using palladium bioinorganic catalyst. Appl. Catal. B Environ. 2016, 199, 108-122. [CrossRef]

17. Akti, F. The effect of potassium modification on structural properties and catalytic activity of copper and iron containing SBA-16 catalysts for selective oxidation of ethanol. Mater. Chem. Phys. 2019, 227, 21-28. [CrossRef]

18. Sánchez, G.; Friggieri, J.; Keast, C.; Drewery, M.; Dlugogorski, B.Z.; Kennedy, E.; Stockenhuber, M. The effect of catalyst modification on the conversion of glycerol to allyl alcohol. Appl. Catal. B Environ. 2014, 152, 117-128. [CrossRef]

19. Zhang, H.; Ke, D.; Cheng, L.; Feng, X.; Hou, X.; Wang, J.; Li, Y.; Han, S. CoPt-Co hybrid supported on amino modified $\mathrm{SiO} 2$ nanospheres as a high performance catalyst for hydrogen generation from ammonia borane. Prog. Nat. Sci. Mater. Int. 2019, 29, 1-9. [CrossRef]

20. Fernandes, A.E.; Jonas, A.M. Design and engineering of multifunctional silica-supported cooperative catalysts. Catal. Today 2018, 334, 173-186. [CrossRef]

21. Feng, X.; Song, Z.; Guo, T.; Yang, R.; Liu, Y.; Chen, X.; Yang, C. Insights into the effect of surface functional groups on catalytic performance for hydrogen generation from sodium borohydride. RSC Adv. 2016, 6, 113260-113266. [CrossRef]

22. Khalili, D.; Banazadeh, A.R.; Etemadi-Davan, E. Palladium Stabilized by Amino-Vinyl Silica Functionalized Magnetic Carbon Nanotube: Application in Suzuki-Miyaura and Heck-Mizoroki Coupling Reactions. Catal. Lett. 2017, 147, 2674-2687. [CrossRef]

23. Miller, J.T.; Mojet, B.L.; Ramaker, D.E.; Koningsberger, D.C. A new model for the metal-support interaction: Evidence for a shift in the energy of the valence orbitals. Catal. Today 2000, 62, 101-114. [CrossRef] 
24. Jin, M.-H.; Park, J.-H.; Oh, D.; Park, J.-S.; Lee, K.-Y.; Lee, D.-W. Effect of the amine group content on catalytic activity and stability of mesoporous silica supported Pd catalysts for additive-free formic acid dehydrogenation at room temperature. Int. J. Hydrogen Energy 2019, 44, 4737-4744. [CrossRef]

25. Vona, D.; Cicco, S.; Ragni, R.; Leone, G.; Lo Presti, M.; Farinola, G. Biosilica/polydopamine/silver nanoparticles composites: New hybrid multifunctional heterostructures obtained by chemical modification of Thalassiosira weissflogii silica shells. MRS Commun. 2018, 8,911-917. [CrossRef]

26. Gupta, R.K.; Kusuma, D.Y.; Lee, P.S.; Srinivasan, M.P. Covalent Assembly of Gold Nanoparticles for Nonvolatile Memory Applications. ACS Appl. Mater. Interfaces 2011, 3, 4619-4625. [CrossRef]

27. Alvarez-Toral, A.; Fernández, B.; Malherbe, J.; Claverie, F.; Pecheyran, C.; Pereiro, R. Synthesis of amino-functionalized silica nanoparticles for preparation of new laboratory standards. Spectrochim. Acta Part B At. Spectrosc. 2017, 138, 1-7. [CrossRef]

28. Sugimura, H.; Hanji, T.; Takai, O.; Masuda, T.; Misawa, H. Photolithography based on organosilane self-assembled monolayer resist. Electrochim. Acta 2001, 47, 103-107. [CrossRef]

29. Pasquardini, L.; Lunelli, L.; Potrich, C.; Marocchi, L.; Fiorilli, S.; Vozzi, D.; Vanzetti, L.; Gasparini, P.; Anderle, M.; Pederzolli, C. Organo-silane coated substrates for DNA purification. Appl. Surf. Sci. 2011, 257, 10821-10827. [CrossRef]

30. Oliveira, R.L.; He, W.; Klein Gebbink, R.J.M.; de Jong, K.P. Palladium nanoparticles confined in thiol-functionalized ordered mesoporous silica for more stable Heck and Suzuki catalysts. Catal. Sci. Technol. 2015, 5, 1919-1928. [CrossRef]

31. Hajipour, A.R.; Mohammadsaleh, F. Triazole-Functionalized Silica Supported Palladium(II) Complex: A Novel and Highly Active Heterogeneous Nano-catalyst for C-C Coupling Reactions in Aqueous Media. Catal. Lett. 2018, 148, 1035-1046. [CrossRef]

32. Yuan, M.; Yang, R.; Wei, S.; Hu, X.; Xu, D.; Yang, J.; Dong, Z. Ultra-fine Pd nanoparticles confined in a porous organic polymer: A leaching-and-aggregation-resistant catalyst for the efficient reduction of nitroarenes by NaBH4. J. Colloid Interface Sci. 2019, 538, 720-730. [CrossRef] [PubMed]

33. Bourane, A.; Elanany, M.; Pham, T.V.; Katikaneni, S.P. An overview of organic liquid phase hydrogen carriers. Int. J. Hydrogen Energy 2016, 41, 23075-23091. [CrossRef]

34. Schrimpf, M.; Esteban, J.; Rösler, T.; Vorholt, A.J.; Leitner, W. Intensified reactors for gas-liquid-liquid multiphase catalysis: From chemistry to engineering. Chem. Eng. J. 2019, 372, 917-939. [CrossRef]

35. Song, J.; Huang, Z.-F.; Pan, L.; Li, K.; Zhang, X.; Wang, L.; Zou, J.-J. Review on selective hydrogenation of nitroarene by catalytic, photocatalytic and electrocatalytic reactions. Appl. Catal. B Environ. 2018, 227, 386-408. [CrossRef]

36. Huang, T.; Fu, Y.; Peng, Q.; Yu, C.; Zhu, J.; Yu, A.; Wang, X. Catalytic hydrogenation of p-nitrophenol using a metal-free catalyst of porous crimped graphitic carbon nitride. Appl. Surf. Sci. 2019, 480, 888-895. [CrossRef]

37. Sharma, S. Metal dependent catalytic hydrogenation of nitroarenes over water-soluble glutathione capped metal nanoparticles. J. Colloid Interface Sci. 2015, 441, 25-29. [CrossRef]

38. Fu, Y.; Qin, L.; Huang, D.; Zeng, G.; Lai, C.; Li, B.; He, J.; Yi, H.; Zhang, M.; Cheng, M.; et al. Chitosan functionalized activated coke for Au nanoparticles anchoring: Green synthesis and catalytic activities in hydrogenation of nitrophenols and azo dyes. Appl. Catal. B Environ. 2019, 255, 117740. [CrossRef]

39. Zarrintaj, P.; Bakhshandeh, B.; Saeb, M.R.; Sefat, F.; Rezaeian, I.; Ganjali, M.R.; Ramakrishna, S.; Mozafari, M. Oligoaniline-based conductive biomaterials for tissue engineering. Acta Biomater. 2018, 72, 16-34. [CrossRef]

40. Amer, I.; Mokrani, T.; Jewell, L.; Young, D.A.; Vosloo, H.C.M. Oxidative copolymerization of p-phenylenediamine and 3-aminobenzenesulfonic acid. Tetrahedron Lett. 2016, 57, 426-430. [CrossRef]

41. Jin, J.-S.; Ning, Y.-Y.; Hu, K.; Wu, H.; Zhang, Z.-T. Solubility of p-Nitroaniline in Supercritical Carbon Dioxide with and without Mixed Cosolvents. J. Chem. Eng. Data 2013, 58, 1464-1469. [CrossRef]

42. Nishioka, R.; Hiasa, T.; Kimura, K.; Onishi, H. Specific Hydration on p-Nitroaniline Crystal Studied by Atomic Force Microscopy. J. Phys. Chem. C 2013, 117, 2939-2943. [CrossRef]

43. Scaffaro, R.; Botta, L.; Lo Re, G.; Bertani, R.; Milani, R.; Sassi, A. Surface modification of poly(ethylene-co-acrylic acid) with amino-functionalized silica nanoparticles. J. Mater. Chem. 2011, 21, 3849-3857. [CrossRef]

44. Jakša, G.; Štefane, B.; Kovač, J. XPS and AFM characterization of aminosilanes with different numbers of bonding sites on a silicon wafer. Surf. Interface Anal. 2013, 45, 1709-1713. [CrossRef] 
45. Latypova, A.; Tarasyuk, I.; Filippov, D.; Lefedova, O.; Bykov, A.; Sidorov, A.; Doluda, V.; Sulman, E. Synthesis, stability and activity of palladium supported over various inorganic matrices in the selective hydrogenation of nitroaniline. React. Kinet. Mech. Catal. 2019, 127, 741-755. [CrossRef]

46. Li, L.; Zhao, H.; Wang, J.; Wang, R. Facile Fabrication of Ultrafine Palladium Nanoparticles with Size- and Location-Control in Click-Based Porous Organic Polymers. ACS Nano 2014, 8, 5352-5364. [CrossRef]

47. Zhong, H.; Liu, C.; Wang, Y.; Wang, R.; Hong, M. Tailor-made porosities of fluorene-based porous organic frameworks for the pre-designable fabrication of palladium nanoparticles with size, location and distribution control. Chem. Sci. 2016, 7, 2188-2194. [CrossRef]

48. Zhang, D.; Jin, C.; Tian, H.; Xiong, Y.; Zhang, H.; Qiao, P.; Fan, J.; Zhang, Z.; Li, Z.Y.; Li, J. An In situ TEM study of the surface oxidation of palladium nanocrystals assisted by electron irradiation. Nanoscale 2017, 9 , 6327-6333. [CrossRef]

49. Chen, A.; Ostrom, C. Palladium-Based Nanomaterials: Synthesis and Electrochemical Applications. Chem. Rev. 2015, 115, 11999-12044. [CrossRef]

50. Blosi, M.; Ortelli, S.; Costa, A.L.; Dondi, M.; Lolli, A.; Andreoli, S.; Benito, P.; Albonetti, S. Bimetallic Nanoparticles as Efficient Catalysts: Facile and Green Microwave Synthesis. Materials 2016, 9, 550. [CrossRef] [PubMed]

51. Kha, N.T.T.; Merkin, A.A.; Komarov, A.A.; Korpatenkov, D.O.; Lefedova, O.V. Kinetics of catalytic hydrogenation of 4-nitroaniline in aqueous solutions of propan-2-ol with acid or base additives. Russ. J. Phys. Chem. A 2014, 88, 588-590. [CrossRef]

52. Doluda, V.Y.; Sidorov, A.I.; Sulman, E.M.; Latypova, A.R.; Filippov, D.V.; Lefedova, O.V. Synthesis, structure and catalytic properties of Pd nanostructured materials in p-nitroaniline catalytic hydrogenation. Izv. Vyssh. Uchebnykh Zaved. Khimiya Khimicheskaya Tekhnol. 2019, 62, 60-68. [CrossRef]

(C) 2020 by the authors. Licensee MDPI, Basel, Switzerland. This article is an open access article distributed under the terms and conditions of the Creative Commons Attribution (CC BY) license (http://creativecommons.org/licenses/by/4.0/). 